\title{
STUDI META ANALISIS PROBLEM BASED LEARNING DALAM PEMBELAJARAN FISIKA
}

\author{
Reny Dwi Astutik¹), Mukhayyarotin Niswati Rodliyatul Jauhariyah'1) \\ 1)Program Studi Pendidikan Fisika, FMIPA, Universitas Negeri Surabaya, Surabaya, Jawa Timur, Indonesia \\ Corresponding author : Reny Dwi Astutik \\ E-mail : renydwi100499@gmail.com
}

\section{Diterima 15 April 2021, Direvisi 05 Mei 2021, Disetujui 06 Mei 2021}

\begin{abstract}
ABSTRAK
Penelitian ini bertujuan untuk menganalisis pengaruh problem based learning dalam pembelajaran fisika yang ditinjau secara keseluruhan, jenjang pendidikan, hasil penelitian atau variabel respon, materi, dan media yang digunakan. Metode penelitian ini menggunakan meta analisis. Adapun alur penelitian meta analisis adalah menentukan topik penelitian, menetapkan kriteria pemilihan data, mencari data, mengelompokkan informasi data, kemudian menganalisis data dan menyimpulkan. Teknik pengumpulan data menggunakan data sekunder yang berasal dari penelitian terdahulu berupa 23 artikel publikasi ilmiah. Teknik analisis data menggunakan besaran effect size. Hasil meta analisis ini menyimpulkan bahwa penerapan problem based learning berpengaruh besar dalam pembelajaran fisika dengan nilai effect size rata-rata sebesar 0,524 . Penerapan problem based learning dalam pembelajaran fisika berpengaruh besar apabila diterapkan pada jenjang perguruan tinggi, menghasilkan output meningkatkan kemampuan berpikir kreatif, menggunakan pokok bahasan cahaya, dan dibantu media pembelajaran secara virtual berupa video based laboratory.
\end{abstract}

Kata kunci: meta analisis; problem based learning; pembelajaran fisika.

\begin{abstract}
This study aims to analyze the effect of problem-based learning in physics learning that is reviewed as overall, school level, research results or response variables, subject matter, and the media used. This research method uses meta-analysis. The meta-analysis research stage is to determine the research topic, determine data selection criteria, search for data, classify data information, then analyze the data and making conclusion. The data collection technique uses secondary data from previous research of 23 scientific publication articles. The data analysis technique uses the effect size. The results of this meta-analysis concluded that the implementation of problem-based learning had a great effect on learning physics with an average effect size of 0.524 . The application of problem-based learning in physics learning had a great effect when applied at the tertiary level, increasing creative thinking skills, using light as the subject matter, and assisted by virtual learning media in the form of a video-based laboratory.
\end{abstract}

Keywords: meta-analysis; problem-based learning; physics learning.

\section{PENDAHULUAN}

Pendidikan merupakan salah satu program pembangunan nasional untuk menghasilkan peningkatan kualitas SDM (sumber daya manusia) dan mencerdasakan kehidupan bangsa. Pendidikan dijadikan sebagai pengembangan potensi peserta didik melalui suasana dan proses pembelajaran yang sadar dan terencana (Depdiknas, 2003). Memasuki abad 21, perkembangan pendidikan semakin pesat. Pendidikan di abad 21 menuntut peserta didik memiliki beragam keterampilan. Keterampilan abad 21 yang harus dimiliki peserta didik adalah $4 \mathrm{Cs}$ yaitu creativity (kreativitas), critical thinking (berpikir kritis), communication (kemampuan komunikasi), dan collaboration (kolaborasi) (National Education Association, 2012).

Indonesia melakukan perubahan dan pengembangan kurikulum menjadi kurikulum 2013 sebagai upaya dalam pemenuhan keterampilan abad 21 (Redhana, 2019). Kurikulum yang berubah menjadi kurikulum 2013 mengharapkan peserta didik dapat meningkatkan keaktifan, kreativitas, dan inovasi. Pada proses pembelajarannya, peserta didik mampu secara aktif melakukan kegiatan pengamatan, bertanya, menganalisis, dan mengomunikasikan hasil pengamatan dalam presentasi. Pengembangan kurikulum 2013 juga dapat menjadikan peserta didik memiliki 3 kompetensi, yaitu kompetensi pengetahuan, 
sikap dan keterampilan (Sofyan \& Komariah, 2016). Paradigma pembelajaran juga mengalami perubahan sebagai pemenuhan pendidikan abad 21 pada tabel berikut.

Tabel 1. Paradigma pendidikan nasional abad 21 (BSNP, 2010)

\begin{tabular}{|c|c|}
\hline $\begin{array}{l}\text { Paradigma } \\
\text { Pembelajaran Lama }\end{array}$ & $\begin{array}{l}\text { Paradigma } \\
\text { Pembelajaran Baru }\end{array}$ \\
\hline $\begin{array}{l}\text { Berpusat pada } \\
\text { pendidik }\end{array}$ & $\begin{array}{l}\text { Berpusat pada } \\
\text { peserta didik }\end{array}$ \\
\hline Satu arah & Interaktif \\
\hline Isolasi & Lingkungan jejaring \\
\hline Pasif & Aktif menyelidiki \\
\hline Maya abstrak & Konteks dunia nyata \\
\hline Pembelajaran mandiri & $\begin{array}{l}\text { Pembelajaran } \\
\text { berbasis tim }\end{array}$ \\
\hline Luas & $\begin{array}{l}\text { Perilaku khas } \\
\text { membe } \\
\text { rdayakan } \\
\text { kaidah keterikatan }\end{array}$ \\
\hline Stimulus tunggal & $\begin{array}{l}\text { Stimulus ke segala } \\
\text { arah }\end{array}$ \\
\hline Alat tunggal & Alat multimedia \\
\hline Hubungan satu arah & Kooperatif \\
\hline Produksi massa & $\begin{array}{l}\text { Kebutuhan } \\
\text { pelanggan }\end{array}$ \\
\hline Usaha sadar tunggal & Jamak \\
\hline Kontrol terpusat & $\begin{array}{l}\text { Otonomi dan } \\
\text { kepercayaan }\end{array}$ \\
\hline Pemikiran faktual & Pemikiran kritis \\
\hline $\begin{array}{l}\text { Penyampaian } \\
\text { pengetahuan }\end{array}$ & $\begin{array}{l}\text { Pertukaran } \\
\text { pengetahuan }\end{array}$ \\
\hline
\end{tabular}

Fisika menjadi salah satu mata pelajaran dalam kurikulum 2013 yang harus dikuasai peserta didik. Untuk mengintegrasikan keterampilan abad 21 kurikulum 2013 pada mata pelajaran fisika, maka perlu upaya dalam proses pembelajaran oleh pendidik melalui model pembelajaran. Menerapkan model problem based learning (PBL) dan project based learning (PjBL) dalam kegiatan proses pembelajaran mampu melatihkan keterampilan abad 21 pada peserta didik (Mayasari dkk., 2016). Menurut Prayogi (2020) model pembelajaran $\mathrm{PjBL}$, $\mathrm{PBL}$ dan cooperative learning dapat digunakan pendidik sebagai model pembelajaran alternatif untuk pemenuhan keterampilan abad 21. Sedangkan Menurut Edens (2000) implementasi model PBL dalam proses pembelajaran oleh pendidik dapat memenuhi keterampilan abad 21 yang harus dimiliki peserta didik.

PBL merupakan model pembelajaran yang menghadapkan permasalahan kehidupan nyata pada peserta didik dan memecahkan permasalahan melalui kegiatan penyelidikan dengan kelompok-kelompok belajar yang kecil (Arends, 2012). Karakteristik PBL menunjukkan bahwa peserta didik menjadi pusat pembelajaran (student centered learning) sehingga diharapkan peserta didik akan mampu mengembangkan kemampuan berpikir tingkat tinggi, meningkatkan keterampilan kolaboratif, meningkatkan kreativitas, meningkatkan pemahaman bermakna, memfasilitasi pemecahan masalah, meningkatkan metakognisi, dan membangun kerja tim (Sofyan \& Komariah, 2016).

Hasil penelitian topik PBL sudah banyak dipublikasikan dalam bentuk artikel ilmiah pada berbagai jurnal. Nurhasanah \& Haratua (2017) dalam penelitiannya menemukan artikel tentang PBL sebanyak 196 buah. Artikel dengan topik PBL tersebut dipublikasi dalam rentang tahun 2010-2015 dari jurnal perguruan tinggi Indonesia melalui mesin pencarian google. Sedangkan pada rentang tahun 2015-2020 menggunakan kata kunci "problem based learning" dan "fisika" didapatkan artikel sebanyak 998 buah. Hasil artikel tersebut dicari melalui publish or perish dengan mesin pencari google scholar yang dapat dilihat pada Gambar $1 .$.

$\begin{array}{lr}\text { Results } & \text { Help } \\ \text { Publication years: } & 2015-2020 \\ \text { Citation years: } & 6(2015-2021) \\ \text { Papers: } & 998 \\ \text { Citations: } & 5362 \\ \text { Cites/year: } & 893.67 \\ \text { Cites/paper: } & 5.37 \\ \text { Authors/paper: } & 2.09 \\ \text { h-index: } & 32 \\ \text { g-index: } & 44 \\ \text { hI,norm: } & 20 \\ \text { hI,annual: } & 3.33 \\ \text { hA-index: } & 14 \\ \text { Papers with ACC }>=1,2,5,10,20:\end{array}$

Gambar 1. Hasil pencarian melalui publish or perish dengan mesin pencari google scholar

Berdasarkan temuan tersebut maka penelitian PBL memiliki hasil penelitian yang beragam dan berpengaruh terhadap kemampuan dan keterampilan peserta didik. Penelitian yang dilakukan oleh Yulianti \& Gunawan (2019) menunjukkan bahwa penerapan model PBL efektif dalam meningkatkan keterampilan berpikir kritis dan 
pemaham konsep peserta didik. Menurut Puspitasari, dkk (2020) hasil belajar dan keterampilan berpikir tingkat tinggi peserta didik menunjukkan adanya signifikansi setelah implementasi model PBL. Penelitian Hartati (2016) menyimpulkan bahwa model PBL dapat digunakan dalam meningkatkan literasi sains peserta didik dengan baik. Penelitian Elizabeth \& Sigahitong (2018); (Najib dkk., 2017); dan (Wartono dkk., 2018) menyimpulkan bahwa model PBL berpengaruh terhadap keterampilan berpikir kreatif peserta didik. Penelitian Putri \& Jatmiko (2018); Astuti \& Supardiyono (2019); Hidaayatullaah \& Dwioranto (2019) menyimpulkan bahwa implementasi PBL dapat meningkatkan kemampuan pemecahan masalah peserta didik dalam pembelajaran fisika.

Beberapa penelitian juga mengintegrasikan strategi tertentu dalam implementasi PBL. Penelitian Permatasari \& Jauhariyah (2020) mengintegrasikan strategi Means-End-Analysis dengan PBL dalam pembelajaran fisika dan menunjukkan peningkatan keterampilan pemecahan masalah. Penelitian Azninda \& Setyarsih (2018) mengintegrasikan strategi self regulated dengan $\mathrm{PBL}$ menunjukkan peningkatan kemampuan pemecahan masalah pada peserta didik. Sedangkan penelitian Haryanti \& Setyarsih (2020) mengintegrasikan strategi $P D E O D E$ dengan $\mathrm{PBL}$ juga menunjukkan peningkatan kemampuan pemecahan masalah pada peserta didik.

Penelitian ini menggunakan 23 artikel penelitian terdahulu yang memiliki topik PBL dalam pembelajaran fisika. Pemilihan 23 artikel tersebut menjadi data penelitian melalui seleksi berdasarkan kriteria-kriteria tertentu. Hasil data berupa 23 artikel tersebut kemudian dipetakan berdasarkan kata kunci penelitian melalui aplikasi VOSviewer untuk melihat keterkaitan dan kepadatannya. Menggunakan kata kunci "problem based learning" pada VOSviewer, keterkaitan PBL dapat dilihat melalui visualisasi gambar 2 berikut.

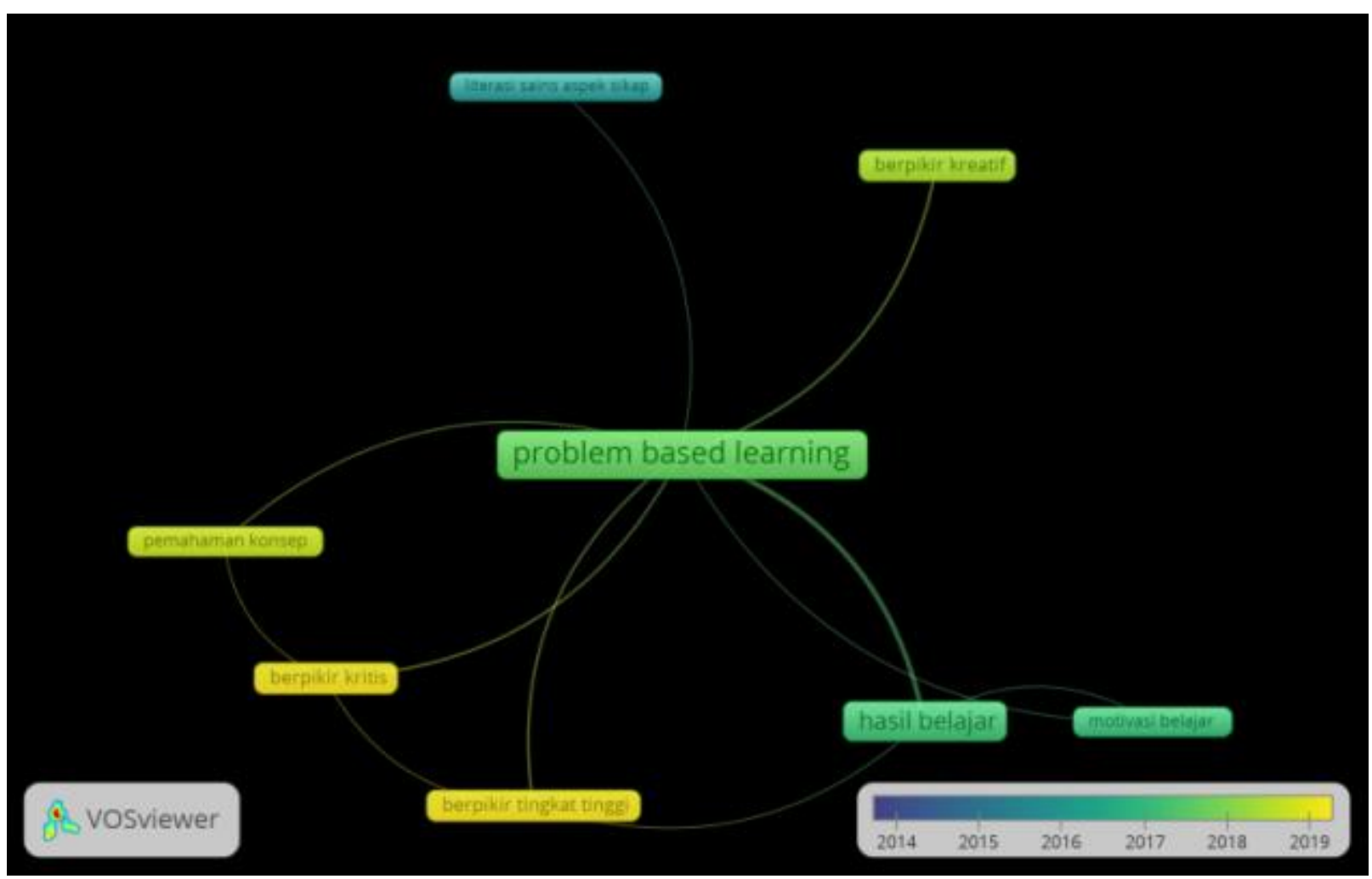

Gambar 2. Visualisasi PBL di VOSviewer menggunakan overlay visualisation

Berdasarkan gambar 2, kata kunci "problem based learning" memiliki keterkaitan dengan hasil belajar, berpikir kritis, berpikir kreatif, berpikir tingkat tinggi, pemahaman konsep, literasi sains, dan motivasi belajar. Untuk mengetahui seberapa besar keterkaitan PBL, maka dapat dilihat gambar 3. Pada setiap kata kunci memiliki warna gradasi menuju gelap yang menunjukkan kepadatan atau banyaknya kata kunci muncul dalam sebuah penelitian. Berdasarkan hal tersebut, implementasi PBL yang banyak diteliti adalah keterkaitan PBL terhadap hasil belajar peserta didik. 


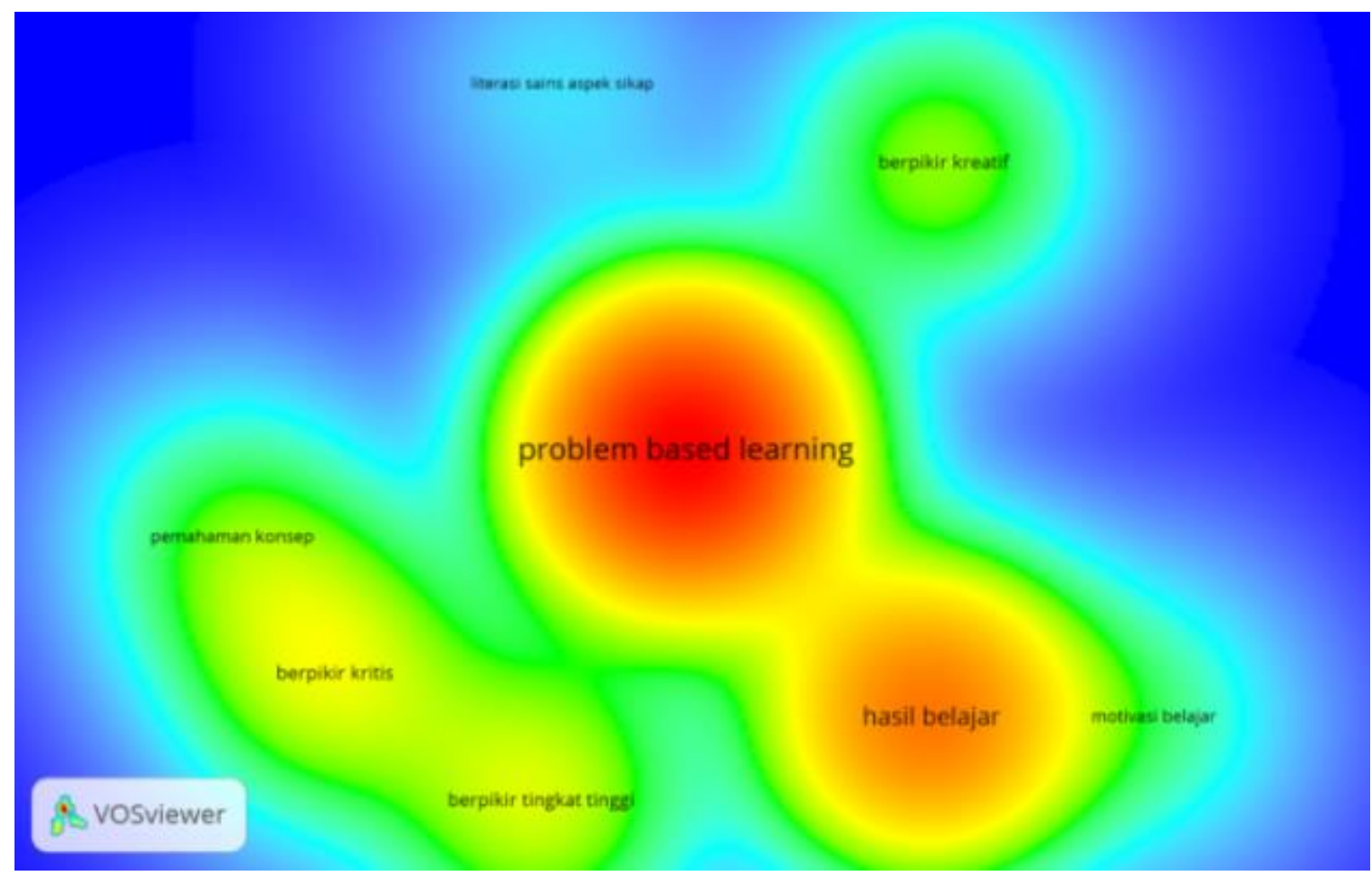

Gambar 3. Visualisasi PBL di VOSviewer menggunakan density visualisation

\begin{abstract}
Visualisasi VOSviewer hanya menunjukkan keterkaitan dan kepadatan penelitian PBL terhadap kemampuan dan keterampilan peserta didik saja sedangkan penelitian lanjutan yang membahas secara keseluruhan seperti pengaruhnya terhadap jenjang pendidikan, materi pembelajaran, dan media yang digunakan belum banyak dilakukan. Berdasarkan uraian tersebut, maka dilakukan penelitian yang berjudul "Studi Meta Analisis Problem Based Learning dalam Pembelajaran Fisika". Penelitian ini mengkaji hasil penelitian terdahulu secara mendalam dan detail berdasarkan meta data yang telah ada. Hasil penelitian ini dapat dijadikan pendidik sebagai referensi model PBL yang tepat dan efektif untuk diterapkan kepada peserta didik.
\end{abstract}

\section{METODE PENELITIAN}

Penelitian ini merupakan jenis penelitian kepustakaan dengan tujuan menganalisis implementasi $\mathrm{PBL}$ dalam pembelajaran fisika menggunakan metode meta analisis. Meta analisis merupakan metode statistik yang meggabungkan data hasil penelitian-penelitian terdahulu sejenis untuk dikaji dan memperoleh sintesis secara umum. Meta analisis dalam dunia pendidikan bertujuan untuk mengetahui signifikansi suatu subjek penelitian setelah adanya perlakuan atau treatment (Merriyana, 2006). Tahapan penelitian ini sesuai dengan langkah-langkah meta analisis yang dapat dilihat pada diagram alur yang disajikan pada gambar 4 .

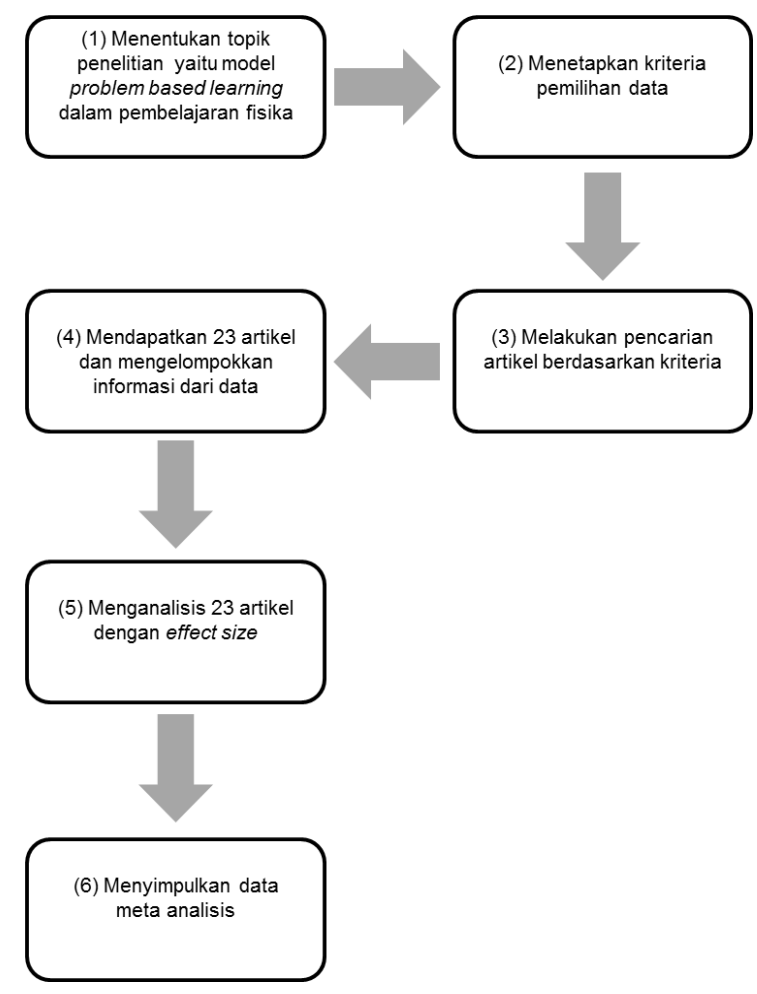

Gambar 4. Alur Penelitian Meta Analisis

Teknik pengumpulan data penelitian menggunakan data sekunder yang berasal dari penelitian terdahulu berupa artikel publikasi ilmiah dengan kriteria sebagai berikut: (1) artikel topik PBL pada fisika; (2) artikel berasal dari jurnal yang terakreditasi SINTA peringkat satu sampai peringkat empat; (3) artikel dipublikasi 
dalam rentang tahun 2015-2020; (4) artikel menggunakan jenis quasi eksperimen; (5) artikel memenuhi data statistik dalam perhitungan effect size; dan (6) memiliki data informasi hasil penelitian atau variabel respon, jenjang pendidikan, materi pelajaran, dan media yang digunakan. Proses pengumpulan data dapat dipermudah menggunakan coding data. Coding data merupakan proses mencari data penelitian menggunakan instrumen pemberian kode sehingga data yang diperoleh sesuai kriteria dan memenuhi syarat secara eksplisit. Hasil coding data dapat melaporkan sebuah studi masuk atau tidak dalam data penelitian (Cooper dkk., 2019). Informasi hasil coding data kemudian dikelompokkan pada Tabel 2.

Tabel 2. Pengelompokan informasi data

\begin{tabular}{|c|c|c|c|}
\hline Keterangan & Jenjang & Materi & Media \\
\hline PT & 1 & & \\
\hline SMA & 9 & & \\
\hline SMP & 12 & & \\
\hline SD & 1 & & \\
\hline $\begin{array}{l}\text { Suhu dan } \\
\text { Kalor }\end{array}$ & & 4 & \\
\hline Optik & & 4 & \\
\hline Gerak & & 2 & \\
\hline Cahaya & & 2 & \\
\hline Globalisasi & & 2 & \\
\hline Fluida Statis & & 1 & \\
\hline $\begin{array}{l}\text { Fluida } \\
\text { Dinamis }\end{array}$ & & 1 & \\
\hline $\begin{array}{l}\text { Listrik } \\
\text { Dinamis }\end{array}$ & & 1 & \\
\hline Elastisitas & & 1 & \\
\hline $\begin{array}{l}\text { Usaha } \\
\text { Energi, } \\
\text { momentum, } \\
\text { implus }\end{array}$ & & 1 & \\
\hline Tekanan & & 1 & \\
\hline Siklus Air & & 1 & \\
\hline Tata Surya & & 1 & \\
\hline $\begin{array}{l}\text { Getaran } \\
\text { Harmonik }\end{array}$ & & 1 & \\
\hline LKPD & & & 10 \\
\hline Simulasi & & & 1 \\
\hline $\begin{array}{l}\text { Video based } \\
\text { laboratory }\end{array}$ & & & 1 \\
\hline Web & & & 1 \\
\hline Non Media & & & 10 \\
\hline Jumlah & 23 & 23 & 23 \\
\hline
\end{tabular}

Teknik analisis pada penelitian ini adalah teknik statistik deskriptif yang menggunakan perhitungan besaran pengaruh (effect size). Effect size digunakan sebagai indikator yang mengukur besarnya efek dari suatu perlakuan atau hubungan antar variabel dalam penelitian. Jika sebuah penelitian ekperimen menggunakan dua kelompok, yaitu kelompok kontrol, kelompok eksperimen, menggunakan uji t sebagai analisis komparasi, maka effect size dapat dihitung melalui persamaan eta-square $\left(\eta^{2}\right)$.

$\eta^{2}=\mathrm{r}^{2}=\frac{t_{0}^{2}}{t_{0}^{2}+d b}$

(Kadir, 2017)

Jika sebuah penelitian eksperimen memiliki asumsi kelompok heterogen dua kelompok, maka effect size dapat dihitung melalui persamaan berikut ini :

$\Delta=\frac{\overline{\mathrm{X}}_{E-} \overline{\mathrm{X}}_{K}}{S_{K}}$

Glass dalam (Kadir, 2017)

Hasil perhitungan effect size selanjutnya diinterpretasi ke dalam kriteria yang dibuat oleh Gravetter dan Wallnau dalam (Anadiroh, 2019) pada Tabel 3.

Tabel 3. Kriteria effect size

\begin{tabular}{ll}
\hline Effect Size & Kriteria \\
\hline $0,01<$ Effect Size $\leq 0,09$ & Efek Kecil \\
$0,09<$ Effect Size $\leq 0,25$ & Efek Sedang \\
Effect Size> 0,25 & Efek Besar \\
\hline
\end{tabular}

\section{HASIL DAN PEMBAHASAN}

Penelitian meta analisis ini mengunakan 23 artikel yang relevan dengan tujuan penelitian dan kriteria pemilihan data. Data yang dikumpulkan dianalisis menggunakan effect size untuk mengetahui pengaruh $\mathrm{PBL}$ dalam pembelajaran fisika. Pada tabel 4, dapat dilihat besar effect size dari keseluruhan artikel. Masing-masing artikel dikategorikan dalam besaran effect size, dimana terdapat lima belas artikel dengan nilai effect size dengan kategori besar, enam artikel dengan nilai effect size dengan kategori sedang, dan dua artikel dengan nilai effect size dengan kategori kecil. Kemudian nilai effect size masing-masing artikel diakumulasikan dan dirata-rata sehingga menghasilkan nilai effect size keseluruhan sebesar 0,524 dengan kategori efek besar. Hasil tersebut menunjukkan adanya pengaruh besar implementasi PBL yang dilakukan pendidik dalam pembelajaran fisika. Hasil tersebut juga bersesuaian dengan penelitian Nurhasanah \& Haratua (2017) yang mendapatkan nilai ratarata effect size keseluruhan sebesar 0,87 dengan kategori efek besar dari 30 artikel PBL yang termuat di jurnal online Indonesia. 
Tabel 4. Effect Size Keseluruhan Artikel

\begin{tabular}{|c|c|c|c|c|}
\hline No & Kode & $\begin{array}{l}\text { Effect } \\
\text { Size }\end{array}$ & Kategori & $\mathbf{N}$ \\
\hline 1. & $2 \mathrm{~A}$ & 0,722 & \multirow{15}{*}{ Besar } & \multirow{15}{*}{15} \\
\hline 2. & $4 \mathrm{~A}$ & 0,587 & & \\
\hline 3. & $5 \mathrm{~A}$ & 0,582 & & \\
\hline 4. & $14 \mathrm{~A}$ & 0,854 & & \\
\hline 5. & $15 \mathrm{~A}$ & 0,800 & & \\
\hline 6. & $17 \mathrm{~A}$ & 0,566 & & \\
\hline 7. & $16 \mathrm{~A}$ & 0,536 & & \\
\hline 8. & $18 \mathrm{~A}$ & 0,651 & & \\
\hline 9. & $19 \mathrm{~A}$ & 1,289 & & \\
\hline 10. & $21 \mathrm{~A}$ & 0,510 & & \\
\hline 11. & $25 \mathrm{~A}$ & 0,545 & & \\
\hline 12. & $27 \mathrm{~A}$ & 0,883 & & \\
\hline 13. & $28 \mathrm{~A}$ & 1,121 & & \\
\hline 14. & $29 \mathrm{~A}$ & 0,400 & & \\
\hline 15. & $37 \mathrm{~A}$ & 0,790 & & \\
\hline 16. & $3 \mathrm{~A}$ & 0,250 & \multirow{6}{*}{ Sedang } & \multirow{6}{*}{6} \\
\hline 17. & $10 \mathrm{~A}$ & 0,123 & & \\
\hline 18 & $23 \mathrm{~A}$ & 0,151 & & \\
\hline 19. & $30 \mathrm{~A}$ & 0,161 & & \\
\hline 20. & $32 \mathrm{~A}$ & 0,210 & & \\
\hline 21. & $34 \mathrm{~A}$ & 0,172 & & \\
\hline 22. & $24 \mathrm{~A}$ & 0,040 & \multirow[t]{2}{*}{ Kecil } & \multirow{2}{*}{2} \\
\hline 23. & $33 \mathrm{~A}$ & 0,062 & & \\
\hline & ta Effect & $0,524($ & (Besar) & \\
\hline
\end{tabular}

Masing-masing artikel dikelompokkan berdasarkan jenjang pendidikan, yaitu Perguruan Tinggi (PT), SMA, SMP, dan SD. Pada tabel 5, dapat dilihat setiap jenjang pendidikan dihitung nilai dan dikategorikan dalam ukuran effect size. Pada jenjang PT, SMA dan SMP memiliki nilai effect size dengan kategori efek besar. Sedangkan pada jenjang SD memiliki nilai effect size dengan kategori efek sedang. Berdasarkan nilai effect size, maka jenjang perguruan tinggi memiliki nilai effect size paling besar sehingga berpengaruh paling tinggi dalam implementasi PBL pada pembelajaran fisika. Hal ini juga bersesuain dengan penelitian Kadir dkk (2013) pada metaanalisis efektivitas penerapan problem solving dalam pembelajaran sains dan matematika yang menyimpulkan jenjang mahasiswa dan pelatihan guru memiliki pengaruh yang paling tinggi dibandingkan dengan jenjang SMA, SMP, dan SD.

Perbedaan perkembangan kognitif anak bisa menjadi pengaruh terhadap PBL dalam pembelajaran fisika di setiap jenjang pendidikan. Menurut Piaget, perkembangan kognitif masing-masing individu berbeda-beda sehingga dilkasifikasikan menjadi empat tahapan, yaitu tahap sensorimotor, praoperasional, operasioanal konkrit, dan operasional formal (Mu'min, 2013). Perkembangan kognitif individu pada jenjang pendidikan PT, SMA, dan SMP masuk klasifikasi di tahapan operasional formal. Pada tahap operasional formal, anak 12 tahun ke atas sudah memiliki perkembangan kognitif yang kompleks, berpikir secara abstrak, membayangkan kemungkinan-kemungkinan, melakukan idealisasi, dan hipotesis deduktif dalam memecahkan permasalahan. Sedangkan jenjang pendidikan SD masuk pada tahap operasional konkrit yang dimulai pada usia tujuh sampai sebelas tahun, dimana anak dapat mengubah penalaran intuitif menjadi logika hanya dalam situasi konkret, mengklasifikasi menjadi bagian-bagian kecil berbeda, memahami hubungannya, namun masih belum bisa memecahkan permasalahan yang bersifat abstrak (Mu'min, 2013).

Menurut Piaget, perkembangan individu juga dipengaruhi oleh proses asimilasi, akomodasi, dan ekuilibrium. Proses asimilasi terjadi jika individu menerima informasi atau pengalaman baru kemudian disesuaikan dengan struktur kognitif yang dimilikinya. Proses akomodasi terjadi jika individu menyesuaikan struktur kognitifnya dengan informasi atau pengalaman yang baru diterima. Sedangkan proses ekuilibrium atau keseimbangan terjadi jika asimilasi dan akomodasi dilakukan secara terus-menerus (Sutarto, 2017). Pada jenjang perguruan tinggi, mahasiswa kemungkinan akan memilki pengalaman yang lebih banyak, kemudian proses asimilasi, akomodasi dan equilibrium dapat terus menerus terjadi dibandingkan dengan peserta didik di jenjang lainnya. Kemudian efek kematangan psikologis menjadi alasan lain dalam perbedaan besar, sedang, dan kecilnya pengaruh PBL dalam pembelajaran fisika disetiap jenjang pendidikan. Menurut Kadir dkk (2013), jenjang mahasiswa dan guru memiliki efek kematangan psikologis lebih stabil dibandingkan dengan jenjang SMA, SMP, dan SD. Meskipun sebenarnya belum ada bukti secara empiris mengenai kematangan psikologis disetiap jenjang, untuk itu perlu ada kajian lebih lanjut.

Tabel 5. Effect Size Berdasarkan Jenjang Pendidikan

\begin{tabular}{llll}
\hline No. & $\begin{array}{l}\text { Jenjang } \\
\text { Pendidikan }\end{array}$ & $\begin{array}{l}\text { Effect } \\
\text { Size } \\
\text { (ES) }\end{array}$ & Kategori \\
\hline 1. & PT & 0,854 & Besar \\
2. & SMA & 0,417 & Besar \\
3. & SMP & 0,582 & Besar \\
4. & SD & 0,250 & Sedang \\
\hline
\end{tabular}

Tabel 6 menunjukkan data masingmasing artikel yang dikelompokkan berdasarkan variabel respon, kemudian 
Volume 7, Nomor 1, Mei 2021. p-ISSN : 2460-9587 e-ISSN : 2614-7017

dihitung dan dikategorikan dalam ukuran effect size. Pengaruh implementasi PBL pada pembelajaran fisika mempunyai efek besar pada hasil belajar, berpikir kreatif, berpikir tingkat tinggi, pemahaman konsep, berpikir kritis dan literasi sains. Efek besar tersebut tidak terlepas dari proses pembelajaran PBL yang memiliki tahap: (1) orientasi masalah pada peserta didik, dimana pendidik akan menjelaskan tujuan, persyaratan penting, dan memotivasi peserta didik; (2) peserta didik diorganisasi pada kegiatan belajar, dimana pendidik akan membantu mendefinisikan dan mengorganisasi tugas belajar sesuai masalah pada peserta didik; (3) investigasi secara mandiri dan kelompok, dimana pendidik mendorong peserta didik untuk memperoleh informasi terkait, melakukan penyelidikan, menjelaskan dan menjawab permasalahan; (4) pengembangan dan presentasi karya, dimana pendidik membantu peserta didik dalam proses perencanaan, persiapan, dan presentasi karya yang telah dibuat; (5) menganalisis dan mengevaluasi proses pemecahan masalah, dimana pendidik akan membantu kegiatan refleksi penyelidikan yang telah dilakukan oleh peserta didik (Arends, 2012).

Berdasarkan variabel respon yang berefek besar dan tahapan proses PBL yang saling berkaitan, maka bukti bahwa PBL dapat memenuhi keterampilan abad 21 (kreatif, kritis, komunikasi, dan kolaborasi) dalam pembelajaran fisika di kurikulum 2013. Sedangkan pada motivasi belajar memiliki efek yang kecil dengan nilai effect size sebesar 0,058 . Peningkatan motivasi belajar tidak hanya karena model pembelajaran yang menarik seperti PBL, namun tentu ada faktor-faktor lainnya. Menurut Ausubel, motivasi belajar dapat berasal dari faktor intrinsik dan ekstrinsik. Motivasi intrinsik berasal dari diri sendiri sehingga siap secara fisik dan psikis dalam belajar. Sedangkan motivasi ekstrinsik berasal dari luar diri sendiri seperti pendidik, orangtua, teman, dan lainnya dalam menyiapkan belajar (Sutarto, 2017). Hasil pengelompokan berdasarkan variabel respon secara keseluruhan didapatkan kemampuan bepikir kreatif dengan nilai effect size paling besar 0,766 memiliki pengaruh paling tinggi dalam implementasi PBL pada pembelajaran fisika. Hasil penelitian oleh Wartono dkk (2018), Elizabet \& Sigahatong (2018), dan Najib dkk (2017) juga menyimpulkan bahwa implementasi PBL dapat meningkatkan kemampuan berpikir kreatif pada peserta didik.
Tabel 6. Effect Size Berdasarkan Variabel Respon

\begin{tabular}{llll}
\hline No. & $\begin{array}{l}\text { Variabel } \\
\text { Respon }\end{array}$ & $\begin{array}{l}\text { Effect } \\
\text { Size } \\
\text { (ES) }\end{array}$ & Kategori \\
\hline 1. & $\begin{array}{l}\text { Hasil Belajar } \\
\text { Berpikir }\end{array}$ & $\begin{array}{l}0,366 \\
0,766\end{array}$ & $\begin{array}{l}\text { Besar } \\
\text { Besar }\end{array}$ \\
3. & $\begin{array}{l}\text { Kreatif } \\
\text { Berpikir }\end{array}$ & 0,573 & Besar \\
& $\begin{array}{l}\text { Tingkat } \\
\text { Tinggi }\end{array}$ & & \\
4. & $\begin{array}{l}\text { Pemahaman } \\
\text { Kemsep }\end{array}$ & 0,575 & Besar \\
5. & $\begin{array}{l}\text { Kerpikir Kritis } \\
\text { Bensin }\end{array}$ & 0,730 & Besar \\
6. & Literasi Sains & 0,722 & Besar \\
7. & Motivasi & 0,058 & Kecil \\
& Belajar & & \\
\hline
\end{tabular}

Tabel 7 menunjukkan data masingmasing artikel yang dikelompokkan berdasarkan materi pelajaran, kemudian dihitung dan dikategorikan dalam ukuran effect size. Materi suhu dan kalor, optik, gerak, cahaya, globalisasi, fluida statis, fluida dinamis, listrik dinamis, elastisitas, usaha energi, momentum dan implus memiliki efek besar dalam implementasi PBL pada pembelajaran fisika. Materi tekanan dan siklus air memiliki efek yang sedang, sedangkan materi tata surya dan getaran harmonik memiliki efek yang kecil dalam implementasi PBL pada pembelajaran fisika. PBL memiliki karakteristik dimana peserta didik melakukan kegiatan penyelidikan untuk memecahkan permasalahan kehidupan nyata. Berdasarkan hal tersebut, materi dengan efek yang besar mudah dikaitkan dengan permasalahan kehidupan nyata dibandingkan dengan materi yang memiliki efek sedang maupun kecil. Dengan demikian, PBL lebih sesuai digunakan dalam pembelajaran fisika dengan karakter materi yang bersifat nyata (riil). Nilai effect size 0,917 memiliki pengaruh paling tinggi dan cocok dalam implementasi PBL pada pembelajaran fisika adalah materi cahaya. Materi cahaya lebih mudah dikaitkan dalam proses pembelajaran menggunakan PBL. Penelitian Najib dkk (2017) dan Sari dkk (2017) juga memilih materi cahaya dalam implementasi PBL. Pada tahapan orientasi masalah dalam PBL, biasanya peserta didik diberi pertanyaan-pertanyaan yang berkaitan dengan kehidupan nyata sesuai materi yang diajarkan. Sebagai contoh penelitian Sari dkk (2017), peserta didik diberikan pertanyaan "Mengapa kamu bisa melihat bayanganmu di cermin? Mengapa kita cenderung menggunakan cermin datar daripada cermin cekung atau cermin cembung untuk bercermin?'- Pertanyaan tersebut 
relevan dengan kehidupan nyata dan relevan dengan karakteristik PBL.

Tabel 7. Effect Size Berdasarkan Materi Pelajaran

\begin{tabular}{|c|c|c|c|}
\hline No. & $\begin{array}{l}\text { Materi } \\
\text { Pelajaran }\end{array}$ & $\begin{array}{l}\text { Effect } \\
\text { Size } \\
\text { (ES) }\end{array}$ & Kategori \\
\hline 1. & $\begin{array}{l}\text { Suhu dan } \\
\text { Kalor }\end{array}$ & 0,489 & Besar \\
\hline 2. & Optik & 0,621 & Besar \\
\hline 3. & Gerak & 0,483 & Besar \\
\hline 4. & Cahaya & 0,917 & Besar \\
\hline 5. & Globalisasi & 0,442 & Besar \\
\hline 6. & Fluida Statis & 0,651 & Besar \\
\hline 7. & $\begin{array}{l}\text { Fluida } \\
\text { Dinamis }\end{array}$ & 0,582 & Besar \\
\hline 8. & $\begin{array}{l}\text { Listrik } \\
\text { Dinamis }\end{array}$ & 0,883 & Besar \\
\hline 9. & Elastisitas & 0,536 & Besar \\
\hline 10. & $\begin{array}{l}\text { Usaha } \\
\text { Energi, } \\
\text { momentum, } \\
\text { implus }\end{array}$ & 0,587 & Besar \\
\hline 11. & Tekanan & 0,210 & Sedang \\
\hline 12. & Siklus Air & 0,250 & Sedang \\
\hline 13. & Tata Surya & 0,123 & Kecil \\
\hline 14. & $\begin{array}{l}\text { Getaran } \\
\text { Harmonik }\end{array}$ & 0,062 & Kecil \\
\hline
\end{tabular}

Tabel 8 menunjukkan data masingmasing artikel yang dikelompokkan berdasarkan media pembelajaran, kemudian dihitung dan dikategorikan dalam ukuran effect size. Semua kategori media yang digunakan oleh pendidik memiliki efek besar dalam implementasi PBL pada pembelajaran fisika. Nilai effect size 0,790 memiliki pengaruh paling tinggi dan cocok dalam implementasi PBL pada pembelajaran fisika adalah media video based laboratory. Menurut penelitian Saharsa dkk (2018), implementasi model PBL dengan video based laboratory dapat meningkatkan pemahaman konsep fisika peserta didik. Video based laboratory adalah laboratorium berbasis video, dimana video yang digunakan berupa gejala fisika yang ditampilkan melalui komputer, kemudian peserta didik melakukan analisis dan memecahkan sebuah permasalahan.

Media video based laboratory dapat memadukan eksperimental dan teoritik dalam pembelajaran fisika. Video based laboratory dapat merepresentasikan gejala fisika secara riil sesuai karakteristik PBL dalam berbagai bentuk seperti grafik, data kuantitatif, dan persamaan (Saharsa dkk., 2018). Implementasi PBL dengan media video based laboratory juga bersesuaian dengan perubahan paradigma pembelajaran lama ke paradigma pembelajaran baru yaitu pembelajaran satu arah berubah menjadi interaktif dan penggunaan alat tunggal menjadi alat multimedia. Media video based laboratory termasuk ke dalam media virtual yang sejalan dengan abad 21 di mana pendidikan dituntut adanya perkembangan teknologi digital. Kelebihan penggunaan media virtual yaitu lebih menarik perhatian peserta didik, lebih kompleks, dan dapat menjelaskan konsep materi yang bersifat abstrak menjadi nyata. Disamping itu, media virtual dipilih untuk digunakan karena adanya laboratorium yang tidak layak dan alat praktikum yang tidak memadai di sekolah.

Tabel 8. Effect Size Berdasarkan Media

\begin{tabular}{llll}
\multicolumn{3}{c}{ Pembelajaran } \\
\hline No. & Media & $\begin{array}{c}\text { Effect } \\
\text { Size } \\
\text { (ES) }\end{array}$ & Kategori \\
\hline 1. & LKPD & 0,543 & Besar \\
2. & Simulasi & 0,400 & Besar \\
3. & Video & 0,790 & Besar \\
& based & & \\
& laboratory & & Besar \\
4. & Web & 0,587 & Besar \\
5. & Non Media & 0,480 & Besar \\
\hline
\end{tabular}

\section{SIMPULAN DAN SARAN}

Berdasarkan hasil dan pembahasan, penelitian meta analisis ini dapat disimpulkan bahwa penerapan PBL berpengaruh besar dalam pembelajaran fisika dengan nilai effect size rata-rata sebesar 0,524. Penerapan PBL dalam pembelajaran fisika berpengaruh besar apabila diterapkan pada jenjang perguruan tinggi, menghasilkan output meningkatkan kemampuan berpikir kreatif peserta didik, menggunakan pokok bahasan dalam kehidupan nyata seperi materi cahaya, dan dibantu media pembelajaran secara virtual berupa video based laboratory. Diharapkan hasil penelitian ini dapat menjadi rekomendasi pendidik dalam menerapkan PBL dalam pembelajaran fisika. Kemudian dapat menjadi referensi penelitian lain sehingga kajian selanjutnya lebih mendalam dan lengkap.

\section{UCAPAN TERIMAKASIH}

Peneliti menyampaikan terima kasih kepada seluruh dosen Jurusan Fisika Universitas Negeri Surabaya yang telah memberikan kesempatan untuk melakukan penelitian pustaka (literature research) dengan metode meta-analisis sebagai tugas akhir studi sarjana penulis.

\section{DAFTAR RUJUKAN}

Anadiroh, M. (2019). Studi Meta-Analisis Model Pembelajaran Problem Based Learning (PBL). Jakarta: FITK UIN Syarif Hidayatullah Jakarta.

Arends, R. I. (2012). Learning to teach. 
McGraw-Hill Companies.

Astuti, I. R. W., \& Supardiyono. (2019). Penerapan Problem Based Learning Untuk Melatihkan Kemampuan Pemecahan Masalah. Inovasi Pendidikan Fisika Pendidikan Fisika, 8(3), 766-769.

Azninda, H., \& Setyarsih, W. (2018). Penerapan Model Pembelajaran Problem Based Learning Menggunakan Strategi Self Regulated Learning untuk Meningkatkan Kemampuan Problem Solving Peserta Didik. Inovasi Pendidikan Fisika, 7(2), 347-352.

BSNP. (2010). Paradigma pendidikan nasional abad XXI. In Jakarta: BSNP.

Cooper, H., Hedges, L. V, \& Valentine, J. C. (2019). The handbook of research synthesis and meta-analysis. Russell Sage Foundation.

Depdiknas. (2003). Undang-undang Republik Indonesia nomor 20 tahun 2003 tentang sistem pendidikan nasional. Departemen Pendidikan Nasional.

Edens, K. M. (2000). Preparing problem solvers for the 21st century through problembased learning. College Teaching, 48(2), 55-60.

Elizabeth, A., \& Sigahitong, M. M. (2018). Pengaruh Model Problem Based Learning Terhadap Kemampuan Berpikir Kreatif Peserta Didik SMA. Prisma Sains: Jurnal Pengkajian IImu dan Pembelajaran MIPA, 6(2), 66-76.

Hartati, R. (2016). Peningkatan aspek sikap literasi sains siswa SMP melalui penerapan model problem based learning pada pembelajaran IPA terpadu. Edusains, 8(1), 90-97.

Haryanti, I. H., \& Setyarsih, W. (2020). Penerapan Model Problem Based Learning (PBL) Menggunakan Strategi PDEODE untuk Melatihkan Problem Solving Skills Peserta Didik di SMA. Inovasi Pendidikan Fisika, 9(1), 1-5.

Hidaayatullaah, H. N., \& Dwikoranto. (2019). Implementasi Problem Based Learning Untuk Melatihkan Kemampuan Problem Solving Fisika Peserta Didik. Inovasi Pendidikan Fisika Pendidikan Fisika, 8(2), 712-715.

Kadir, K. (2017). Meta-Analysis of the Effect of Learning Intervention Toward Mathematical Thinking on Research and Publication of Student. TARBIYA: Journal of Education in Muslim Society, 4(2), 162175.

Kadir, Milama, B., \& Khairunnisa. (2013). Metaanalisis efektivitas pendekatan problem solving dalam pembelajaran sains dan matematika. Lembaga Penelitian UIN
Syarif Hidayatullah Jakarta.

Mayasari, T., Kadarohman, A., \& Kaniawati, I. (2016). Apakah model pembelajaran problem based learning dan project based learning mampu melatihkan keterampilan abad 21? jurnal pendidikan fisika dan keilmuan, 2(1), 48-55.

Merriyana, R. (2006). Meta analisis penelitian alternatif bagi guru. Jurnal Pendidikan Penabur, 5(06), 102-106.

Mu'min, S. A. (2013). Teori Perkembangan Kognitif Jean Piaget. Al-TA'DIB: Jurnal Kajian IImu Kependidikan, 6(1), 89-99.

Najib, I. A., Suyatna, A., \& Wahyudi, I. (2017). Pengaruh Model Pembelajaran Problem Based Learning terhadap Keterampilan Berpikir Kreatif Siswa SMP. Jurnal Pembelajaran Fisika Universitas Lampung, 5(1), 116912.

National Education Association. (2012). Preparing 21st century students for a global society: An educator's guide to the "Four Cs." In Alexandria, VA: National Education Association.

Nurhasanah, L. S., \& Haratua, T. M. S. (2017). Pengaruh Problem Based Learning Pada Hasil Belajar Fisika: Sebuah Meta-Analisis Artikel Jurnal Online Indonesia. Jurnal Pendidikan dan Pembelajaran Khatulistiwa, 6(3).

Permatasari, N. Y., \& Jauhariyah, M. N. R. (2020). The Students'problem-Solving Skills Improvement By Using Integration Of Means-Ends Analysis On ProblemBased Learning Model. Inovasi Pendidikan Fisika, 9(2), 229-235.

Prayogi, R. D. (2020). Kecakapan Abad 21: Kompetensi Digital Pendidik Masa Depan. Manajemen Pendidikan, 14(2), 144-151.

Puspitasari, R. P., Sutarno, S., \& Dasna, I. W. (2020). Pengaruh Model Problem Based Learning terhadap Kemampuan Berpikir Tingkat Tinggi dan Hasil Belajar Siswa Kelas V SD. Jurnal Pendidikan: Teori, Penelitian, dan Pengembangan, 5(4), 503-511.

Putri, E. A. K., \& Jatmiko, B. (2018). Implementation Of Problem Based Learning In Dynamic Fluid Lesson To Increase Problem Solving Skill Student's Clas XI On Sman 1 Jember. Inovasi Pendidikan Fisika, 7(1), 21-27.

Redhana, I. W. (2019). Mengembangkan keterampilan abad ke-21 dalam pembelajaran kimia. Jurnal Inovasi Pendidikan Kimia, 13(1), 2239-2253.

Saharsa, U., Qaddafi, M., \& Baharuddin, B. (2018). Efektivitas Penerapan Model Pembelajaran Problem Based Learning Berbantuan Video Based Laboratory 
Terhadap Peningkatan Pemahaman Konsep Fisika. Jurnal Pendidikan Fisika, 6(2), 57-64.

Sari, I. N., Wahyudi, W., \& Hendrias, H. (2017). Application of problem based learning model to learning outcomes of student in light matter in the class VIII SMP Negeri 1 Ledo kabupaten Bengkayang. Journal of Physics: Theories and Applications, 1(1), 75-82.

Sofyan, H., \& Komariah, K. (2016). Pembelajaran problem based learning dalam implementasi kurikulum 2013 Di SMK. Jurnal Pendidikan Vokasi, 6(3), 260-271.

Sutarto, S. (2017). Teori kognitif dan implikasinya dalam pembelajaran. Islamic Counseling: Jurnal Bimbingan dan Konseling Islam, 1(2), 1-26.

Wartono, W., Diantoro, M., \& Bartlolona, J. R. (2018). Influence of problem based learning model on student creative thinking on elasticity topics a material. Jurnal Pendidikan Fisika Indonesia, 14(1), 32-39.

Yulianti, E., \& Gunawan, I. (2019). Model Pembelajaran Problem Based Learning (PBL): Efeknya Terhadap Pemahaman Konsep dan Berpikir Kritis. Indonesian Journal of Science and Mathematics Education, 2(3), 399-408. 